\title{
Quality of life in teenagers with strabismus
}

\section{Moosang Kim}

Department of Ophthalmology, School of Medicine, Kangwon National University, Chuncheon, Republic of Korea
Correspondence: Moosang Kim

Department of Ophthalmology, School of Medicine, Kangwon National University, Kangwondaehakgil I, Chuncheon, Kangwon 200-70I, Republic of Korea Tel +82 332582014

Fax +82 332582000

Email kimmoo-79@hanmail.net
This article was published in the following Dove Press journal:

Patient Preference and Adherence

4 November 2016

Number of times this article has been viewed

\section{Dear editor}

I read with great interest the article titled "Impact of strabismus on the quality of life of Chinese Han teenagers" by Tu et al. ${ }^{1}$ They concluded that strabismus could significantly reduce the health-related quality of life $(\mathrm{QoL})$ of Chinese teenagers. I congratulate the authors for their enlightening study and would like to make some contributions to the study topic.

What is QoL? A number of attempts to define QoL have been made, reflecting different approaches to the topic. However, I would like to define QoL as "general well-being defined in health and happiness rather than wealth".

In clinical practice, I see many adult patients with long-standing strabismus, some of them with no vision or light perception. I also have seen teenage boys covering the exodeviated eye with their hair or with a constant head position to look as orthotropic as possible. Many of them did not undergo surgery during their childhood or teenage years. The reason for not having surgery during the childhood period is because the patients' parents were not interested in cosmetic treatment. In other cases, some of them did not have surgery because their doctors advised them against it, saying "It is a blind eye, no need for surgery."

Strabismus has been linked to a poorer QoL, which is primarily attributed to socioeconomic factors and the psychosocial effects of the disease. Affected patients are likely to have more difficulty finding employment than members of the general population, leading to lower overall socioeconomic status. Similarly, difficulty in interacting with other people can lead to altered overall happiness, reducing the QoL.

Therefore, it is highly recommended that the surgery should be performed in teenagers with strabismus. Appearance has a great influence on social functioning.

\section{Disclosure}

The author reports no conflicts of interest in this communication.

\section{Reference}

1. Tu C, Ye L, Jiang L, Wang Y, Li Y. Impact of strabismus on the quality of life of Chinese Han teenagers. Patient Prefer Adherence. 2016;10:1021-1024. 
Dove Medical Press encourages responsible, free and frank academic debate. The content of the Patient Preference and Adherence 'letters to the editor' section does not necessarily represent the views of Dove Medical Press, its officers, agents, employees, related entities or the Patient Preference and Adherence editors. While all reasonable steps have been taken to confirm the content of each letter, Dove Medical Press accepts no liability in respect of the content of any letter, nor is it responsible for the content and accuracy of any letter to the editor.

Patient Preference and Adherence

Dovepress

\section{Publish your work in this journal}

Patient Preference and Adherence is an international, peer-reviewed, open access journal that focuses on the growing importance of patient preference and adherence throughout the therapeutic continuum. Patient satisfaction, acceptability, quality of life, compliance, persistence and their role in developing new therapeutic modalities and compounds to optimize

clinical outcomes for existing disease states are major areas of interest for the journal. This journal has been accepted for indexing on PubMed Central. The manuscript management system is completely online and includes a very quick and fair peer-review system, which is all easy to use. Visit http://www. dovepress.com/testimonials.php to read real quotes from published authors.

Submit your manuscript here: http://www.dovepress.com/patient-preference-and-adherence-journal 